\title{
Glacier winds on Vatnajökull ice cap, Iceland, and their relation to temperatures of its lowland environs
}

\author{
Helgi BJÖRNSSON, Sverrir GUDMUNDSSON, Finnur PÁLSSON
}

Science Institute, University of Iceland, Dunhagi 3, IS-107 Reykjavík, Iceland

E-mail: hb@raunvis.hi.is

\begin{abstract}
During the ablation season, the ice cap Vatnajökull $\left(8100 \mathrm{~km}^{2}\right)$ develops its own microclimate that we describe by meteorological data collected during the summers of 1994-2003. Persistent glacier winds are generated down the melting ice cap, whose variations in speed can be related empirically to the temperature fluctuations of the lowland environs of the ice cap. This suggests that climate warming would be accompanied by stronger glacier winds down the outlets of Vatnajökull, producing stronger turbulent fluxes that might amplify the melting rates in the lower ablation areas.
\end{abstract}

\section{INTRODUCTION}

Vatnajökull is a medium-sized ice cap $\left(8100 \mathrm{~km}^{2}\right)$ located near the North Atlantic Ocean close to the maritime southeastern coast of Iceland (Fig. 1). The ice cap extends $150 \mathrm{~km}$ from west to east and $100 \mathrm{~km}$ from south to north $\left(63^{\circ} 55^{\prime}-64^{\circ} 50^{\prime} \mathrm{N}, 1^{\circ} 15^{\prime}-18^{\circ} 10^{\prime} \mathrm{W}\right)$ with an elevation ranging from sea level up to $2000 \mathrm{~m}$. For zero net balance the ablation zone is about $40 \%$ of the total glacier area, and the equilibrium-line altitude is $1100 \mathrm{~m}$ at the southern outlets and $1300 \mathrm{~m}$ in the northern part (Björnsson and others, 1998). The surroundings of the ice cap are comprised mainly of lava and outwash plains.

Several meteorological experiments have been performed on medium- and small-sized glaciers with significant ablation zones like Vatnajökull (e.g. Van den Broeke, 1997; Oerlemans, 1998; Oerlemans and others, 1999; Oerlemans and Grisogono, 2001; Parmhed and others, 2004). They have described the microclimate created during the summers that is characterized by a shallow downslope wind field, typically $10-50 \mathrm{~m}$ thick. A temperature deficit is created between the boundary layer over the melting glacier and the free atmosphere which generates negative buoyancy forces and gravity winds. Further, warm air may rise outside the margins of the glacier, producing a pressure gradient down-glacier.

In this paper, we describe the temperature and wind climate of Vatnajökull based on observations from 2-15 automatic weather stations (AWSs) during the summers of 1994-2003 (Fig. 1). These long-term observations allow us to derive an empirical relation between the glacier wind speed and the temperature observed at the lowland environs of the ice cap. This can be used for discussion of the impact of glacier winds in a warmer climate.

\section{METEOROLOGICAL OBSERVATIONS}

The AWSs on Vatnajökull were typically operated from early May to the beginning of September and sometimes to late September or early October. The AWSs on the ice cap (Fig. 2) measured the incoming and outgoing shortwave radiation $\left(Q_{i}\right.$, and $Q_{0}$, respectively), incoming and outgoing longwave radiation $\left(I_{i}\right.$ and $I_{0}$, respectively) and wind direction (WD) at $2 \mathrm{~m}$ above the surface. Wind speed $\left(u_{G}\right)$, air temperature $\left(T_{\mathrm{G}}\right)$ and relative humidity $(r)$ were measured at one to four levels. Air pressure was recorded at only one to three stations on the glacier but several stations outside the glacier. The daily changes in surface height were measured directly by a sonic echo sounder (Fig. 2), and the observed snow density used to calculate the corresponding ablation rate $\left(a_{\mathrm{s}}\right)$ in water equivalent. The ablation rate was also calculated directly from the energy components (Fig. 3). A description of the set-up, instrumentation and the calibration and accuracy of the meteorological observations is given by Oerlemans and others (1999). The instruments were calibrated before the fieldwork each year. Air temperature $\left(T_{\mathrm{S}}\right)$ was observed at several AWSs outside the ice cap (Fig. 1). In this paper, we use observations at $2 \mathrm{~m}$ above the glacier surface.

\section{THE MICROCLIMATE OF TEMPERATURE AND WIND}

Typically the ablation season at the margins of Vatnajökull starts in May and ends in late September. At the southern outlets terminating at $100 \mathrm{~m}$ elevation, melting can take place in any month, but at the northern and eastern outlets, terminating at $750-850 \mathrm{~m}$, ablation typically starts from the beginning to end of May, and 1-2 weeks later at the

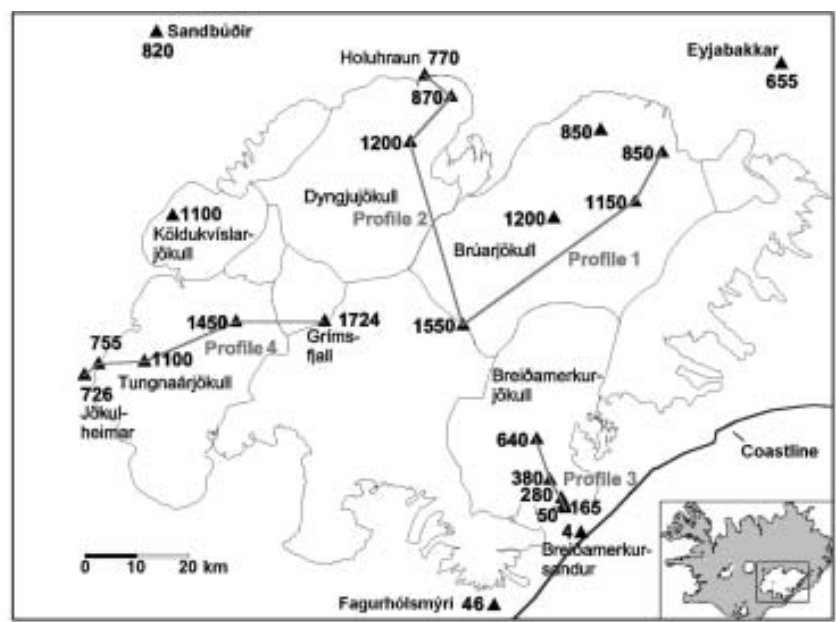

Fig. 1. The sites of AWSs within and outside Vatnajökull. The temperature $\left(T_{\mathrm{S}}\right)$ at Eyjabakkar at $655 \mathrm{~m}$ is related to the wind speed at Brúarjökull outlet, and at Sandbúðir at $820 \mathrm{~m}$ to the wind speed at Köldukvíslarjökull and Tungnaárjökull outlets. 


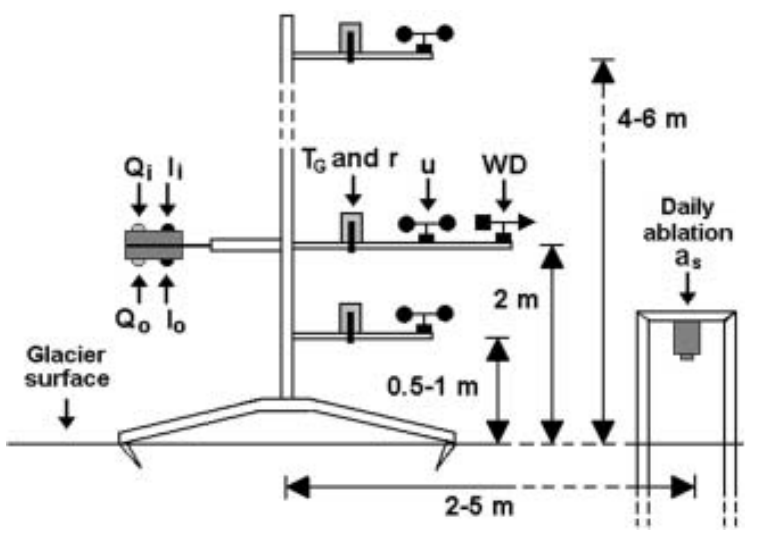

Fig. 2. Schematic graph of an AWS. The instruments are mounted to a mast standing on the melting surface, and the sonic echo sounder on a mast drilled several meters into the glacier. Parameters are defined in section 2 .

equilibrium line (1100-1200 m). During the ablation season, temperatures below freezing point were often observed in the accumulation area, although some sublimation was kept up by the net radiation. At the highest AWS, at Grímsfjall (1724 m; Fig. 1), the summer temperature hovers around $0^{\circ} \mathrm{C}$, and the summer balance at the highest elevations of the glacier is typically slightly negative (Björnsson and others, 1998).

During the reduced cyclonic activity of the summer months, the melting ice cap develops its own microclimate characterized by persistent downslope winds. The air above the glacier boundary layer is warmer than the melting surface, resulting in negative buoyancy forces and gravity winds down the sloping outlets. Furthermore, a large airtemperature difference is set up between the boundary layer over the melting glacier and its low-albedo environs (Fig. 4), and the glacier wind may go together with a pressure gradient set up down-glacier as the warm air rises outside the margins of the glacier. Typically the observed pressure gradient is about 5-10 hPa per $50 \mathrm{~km}$ at western Vatnajökull, and even larger at the southern outlet, Breiðamerkurjökull, which terminates at sea level (profile 3 in Fig. 1). The

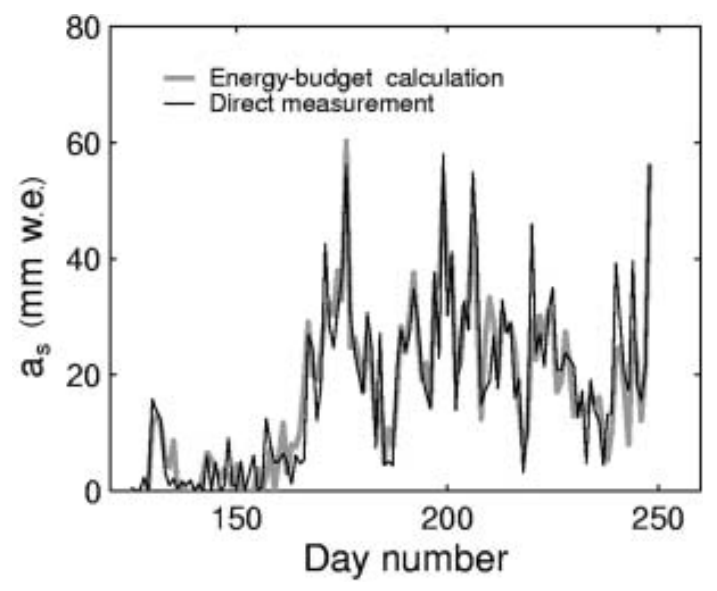

Fig. 3. Comparison of direct ablation measurements and energybudget calculations (Equation (5)). The results show daily melting on Brúarjökull at $1150 \mathrm{~m}$ in 1996.

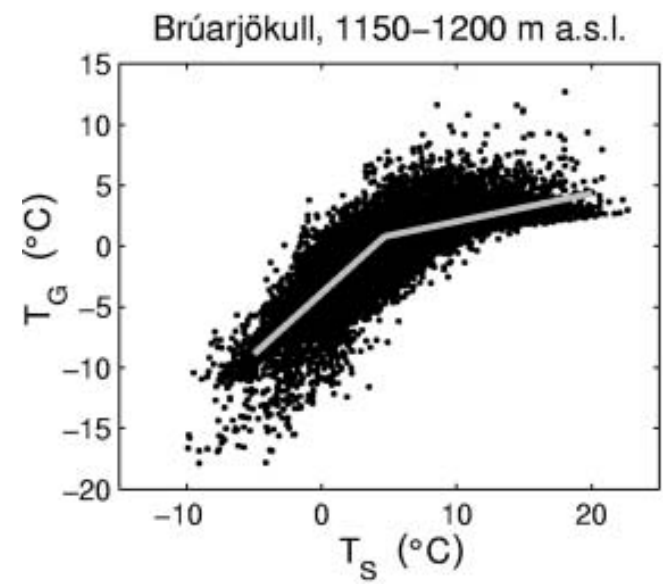

Fig. 4. Example of relationship between air temperatures above the glacier surface $\left(T_{\mathrm{G}}\right)$ and at the stations outside $\left(T_{\mathrm{S}}\right)$, as 1 hour means from 1994 to 2003. Piecewise linear regression between temperatures on and off the glacier is shown as imprinted grey lines (see Equation (1)).

distribution of the wind directions is rather flat on the top of the ice cap but becomes more consistently downslope at the lower elevation (Fig. 5). From September to early May, the conditions for developing the microclimate of the ablation season change and cyclonic weather systems passing Iceland become more influential for the local climate of Vatnajökull.

The downslope glacier wind flow is observed during both day and night in June-August (e.g. $\mathrm{WD}_{\mathrm{Bs} 50}$ in Fig. 6c), but the speed is in general related to the temperature variations (in both $T_{\mathrm{G}}$ and $T_{\mathrm{S}}$; Figs 7 and 8). Larger diurnal variations in glacier winds were observed in the northern and western than in the southern outlets, and in general no acceleration was seen down the broad, gently sloping Brúarjökull, Dyngjujökull and Tungnaárjökull outlets (profiles 1, 2 and 4 in Fig. 1). The glacier winds are strongest and most persistent at the steep south-facing Breiðamerkurjökull where they also accelerate down-glacier and show little variation from day to night. The wind field even survives cyclonic activity producing southerly winds at the coast. At $50 \mathrm{~m}$ elevation on Breiðamerkursandur outwash plain, wind always blows from the glacier (Fig. $6 \mathrm{~b}$ and c), but at the coast ( $4 \mathrm{~m}$ elevation) the wind generally blows from sea to land during the daytime (from the east or southeast) and from land to sea during the night (from the north or northnorthwest) (Fig. 6a-c).

\section{EMPIRICAL RELATION BETWEEN GLACIER WIND SPEED AND AIR TEMPERATURES ON THE LOWLAND OFF THE MELTING ICE CAP}

A piecewise-linear regression of our AWS data gives the relation

$$
\Delta T_{\mathrm{G}}= \begin{cases}a_{1} \Delta T_{\mathrm{S}} & T_{\mathrm{S}} \geq a_{2} \\ \Delta T_{\mathrm{S}} & \text { otherwise }\end{cases}
$$

between the temperature changes in the boundary layers on the glacier $\left(\Delta T_{\mathrm{G}}\right.$ in $\left.{ }^{\circ} \mathrm{C}\right)$ and its close environs $\left(\Delta T_{\mathrm{S}}\right.$ in $\left.{ }^{\circ} \mathrm{C}\right)$. Approximating melting conditions with $T_{\mathrm{G}} \geq 0^{\circ} \mathrm{C}$,

$$
\Delta u_{\mathrm{G}}=\left\{\begin{array}{ll}
b_{1} \Delta T_{S} & T_{\mathrm{G}} \geq 0{ }^{\circ} \mathrm{C} \\
0 & \text { otherwise }
\end{array},\right.
$$



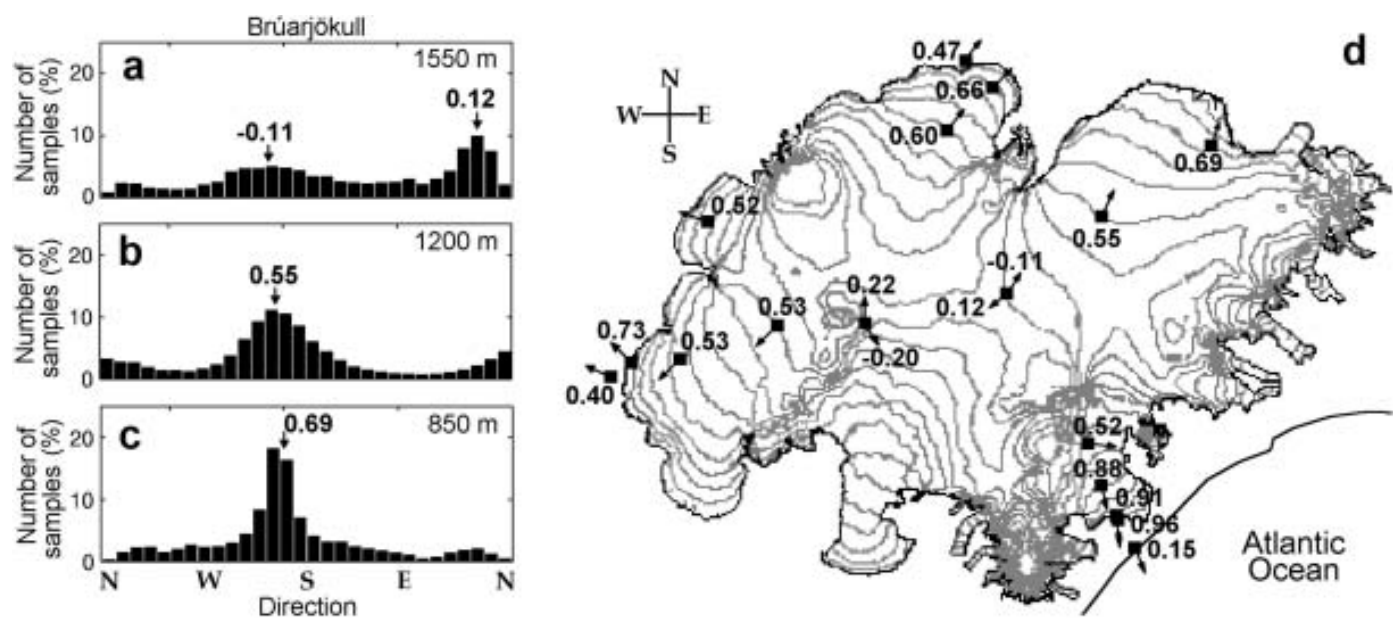

Fig. 5. (a-c) Histograms showing the distribution of wind directions at Brúarjökull at $1550 \mathrm{~m}$ (a), $1200 \mathrm{~m}$ (b) and $850 \mathrm{~m}$ (c); hourly-mean values, June-August 1994-2003. (d) Contour map of Vatnajökull. The arrows show the most frequent wind direction $\theta$ (typically downslope on the glacier) at all the AWSs (Fig. 1), and the corresponding direction number, calculated as

$$
\sum_{i}\left[u_{\mathrm{G} i} \cos \left(\mathrm{WD}_{i}-\theta\right)\right] / \sum_{i} u_{\mathrm{G} i} \forall i
$$

where $i$ is the sample number, $u_{\mathrm{G}}$ the wind speed and WD the wind direction. Thus, for $-1,0$ and 1 wind blows only up-slope, equally from all directions and only downslope, respectively. The direction numbers and the most frequent wind directions for Brúarjökull are also marked on the histograms in (a) and (b).

relates the change in the speed of the glacier wind $\left(\Delta u_{\mathrm{G}}\right.$ in $\mathrm{m} \mathrm{s}^{-1}$ ) to $\Delta T_{\mathrm{S}}$ (Fig. 7c and d). The coefficients $a_{1}, a_{2}$ and $b_{1}$ vary with elevation and between locations on the glacier (Table 1$) ; a_{1}$ and $b_{1}$ display the sensitivity of $T_{\mathrm{G}}$ and $u_{\mathrm{G}}$ at $2 \mathrm{~m}$ above the glacier, respectively, to changes in $T_{S}$. The smallest values of $a_{1}$ are found at lower elevations (Table 1) where the temperature deficit is highest between the free atmosphere and the boundary layer of the melting glacier. In general, the conditions for developing the glacier wind become enhanced down-glacier, and its strength increasingly more sensitive to $T_{\mathrm{S}}$ (Table 1 ; Fig. $9 \mathrm{a}$ and b). The accuracy of $b_{1}$ (Table 1 ) improves with the number of summers observed, increased inclination of the surface and reduced elevation.

Using observations from one summer (1996) and external temperature $\sim 35 \mathrm{~km}$ southwest of Vatnajökull, de Ruyter de Wildt and others (2003) derived different $b_{1}$ values for Brúarjökull (-0.12 to $0.21 \mathrm{~m} \mathrm{~s}^{-1}{ }^{\circ} \mathrm{C}^{-1}$ at $1550-850 \mathrm{~m}$ a.s.l., respectively) and Köldukvíslarjökull $\left(-0.20 \mathrm{~m} \mathrm{~s}^{-1}{ }^{\circ} \mathrm{C}^{-1}\right)$. Their estimate for Dyngjujökull is, however, comparable to our values for Brúarjökull. They also obtained $b_{1}$ in the range $0.12-0.3 \mathrm{~m} \mathrm{~s}^{-1}{ }^{\circ} \mathrm{C}^{-1}$ from 380 down to $165 \mathrm{~m}$ a.s.l., respectively, at Breiðamerkurjökull.

\section{ESTIMATED IMPACT OF GLACIER WIND ON SUMMER MELTING}

Our observations suggest that warmer climate is accompanied by increased speed of glacier winds on Vatnajökull (Table 1; Fig. 7c and d). To quantify the effect of increased turbulent heat fluxes, we have calculated the energy balance at AWSs on Vatnajökull for two scenarios: first, as observed during May-August 1996 and 2000 (at Brúarjökull and Köldukvíslarjökull in 1996 and at Tungnaárjökull in 2000), and, second, superimposing a stepwise temperature increase $\left(\Delta T_{\mathrm{S}}\right)$ on the observed record. The surface topography was assumed to be unchanged and the winter balance $\left(b_{\mathrm{w}}\right)$ was set equal to that observed in 1996 at Brúarjökull and Köldukvíslarjökull and 2000 at Tungnaárjökull.

We consider an increase in regional temperature $\left(\Delta T_{\mathrm{S}}\right)$ as suggested by Jóhannesson and others (2004), based on
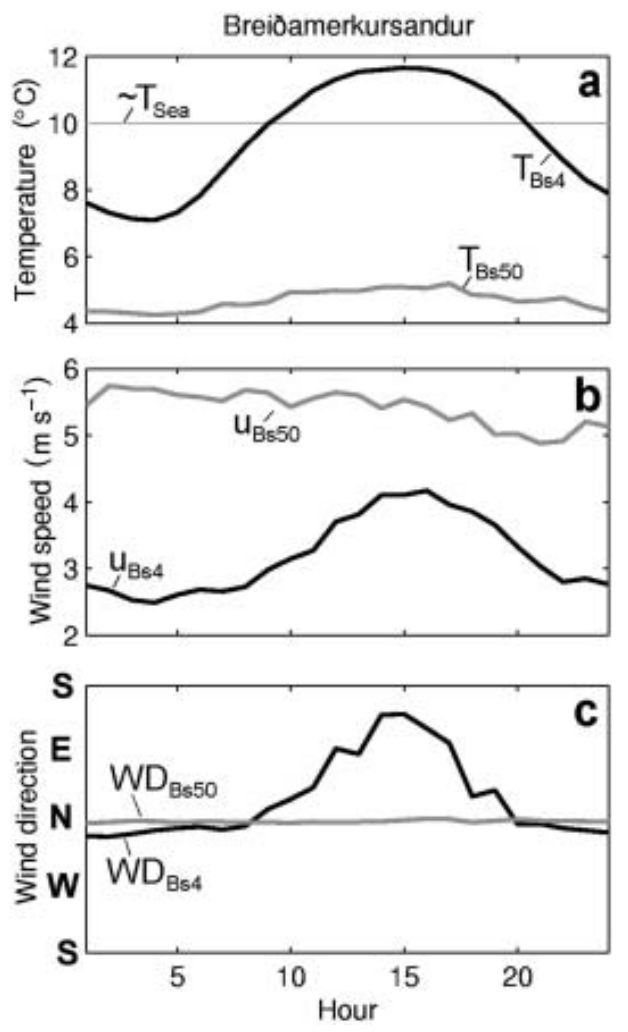

Fig. 6. Mean summer day values (June-August) of (a) temperature, $T$, (b) wind speed, $u$, and (c) wind direction, WD, at Breiðamerkursandur. The subscript Bs4 refers to the coast at $4 \mathrm{~m}$ a.s.l., and Bs50 to the glacier terminus at $50 \mathrm{~m}$ a.s.I. In (a) $T_{\text {sea }}$ shows the sea temperature of $10^{\circ} \mathrm{C}$. 

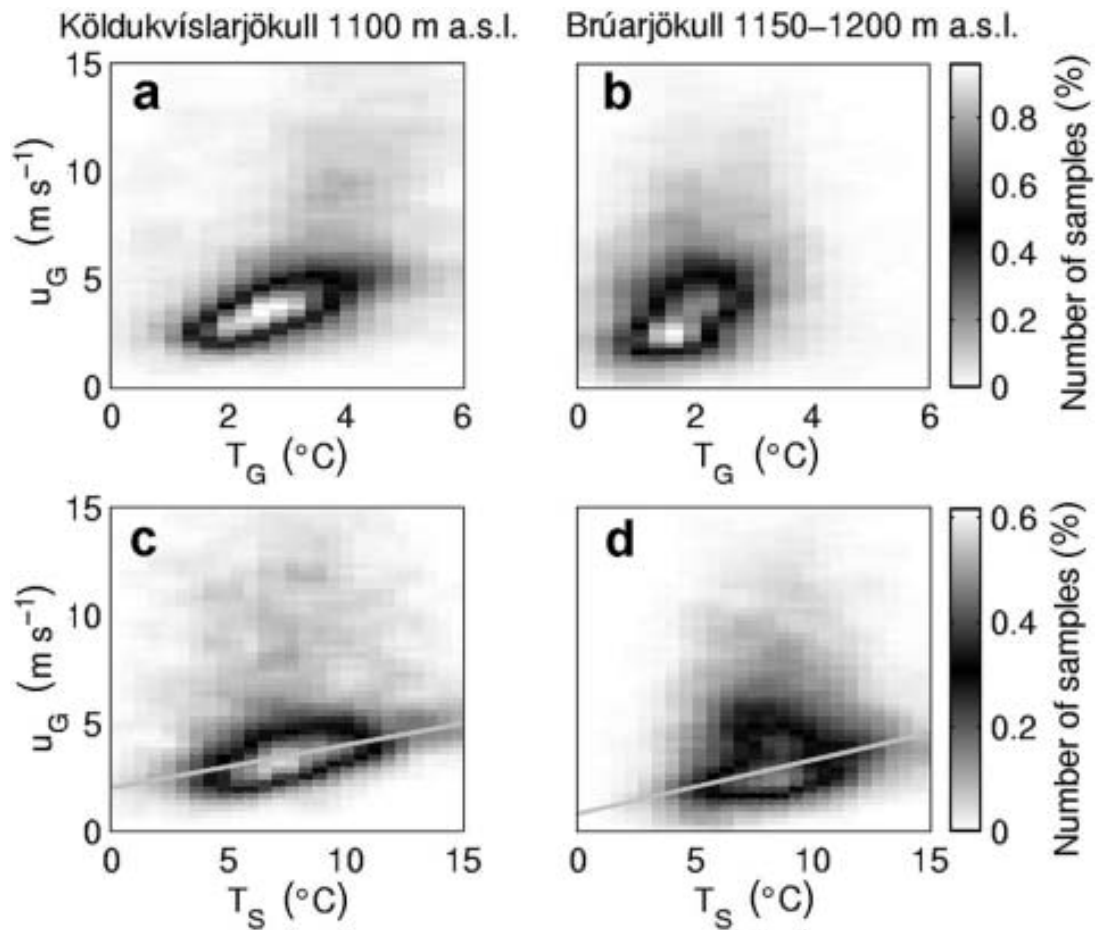

Fig. 7. Variation of the glacier wind speed with temperature at $2 \mathrm{~m}$ above the melting surface $(\mathrm{a}, \mathrm{b})$ and outside the glacier (c, d), shown as three-dimensional histograms with a vertical view. The subplots include 1 hour data from June to August in 1996-2000 at Köldukvíslarjökull at $1100 \mathrm{~m} \mathrm{(a,} \mathrm{c)} \mathrm{and} \mathrm{1994-2003} \mathrm{at} \mathrm{Brúarjökull} \mathrm{at} \mathrm{1150-1200} \mathrm{m} \mathrm{(b,} \mathrm{d).} \mathrm{The} \mathrm{grey} \mathrm{lines} \mathrm{in} \mathrm{(c)} \mathrm{and} \mathrm{(d)} \mathrm{show} \mathrm{the} \mathrm{slope} b_{1}$ in Table 1 and Equation (2).

scenarios for climate change in the North Atlantic area:

$$
\frac{\Delta T_{\mathrm{S}}}{\Delta t}=0.225+0.075 \cos \left(2 \pi \frac{d}{n}-0.46\right),
$$

where $\Delta t$ is one decade, $d$ is Julian day and $n$ the total number of days per year. Equation (3) describes sinusoidal variation within the year, with lowest temperature changes taking place in mid-summer and peaks around mid-winter $\left(+0.15^{\circ} \mathrm{C}\right.$ and $+0.3^{\circ} \mathrm{C}$ per decade, respectively). Here, we only predict temperature changes for May-August, a maximum of $+0.22^{\circ} \mathrm{C}$ per decade in May.

The total energy $\left(M_{C}\right)$ was calculated for a melting glacier surface as

$$
M_{\mathrm{C}}=R+H_{\mathrm{d}}+H_{1},
$$

where $R$ is the net radiation. The sensible $\left(H_{\mathrm{d}}\right)$ and latent $\left(H_{\mathrm{l}}\right)$ heat fluxes were calculated from the wind, temperature and relative humidity at $2 \mathrm{~m}$ above the glacier surface using the Monin-Obukhov model (e.g. Björnsson, 1972). The daily

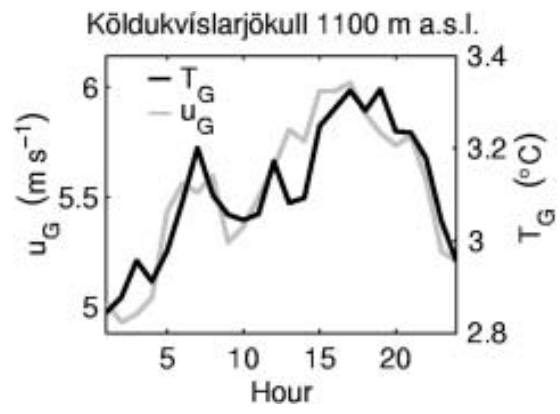

Fig. 8. Mean diurnal variations of temperature and glacier wind, calculated using the data in Figure 7a. ablation was calculated as

$$
a_{\mathrm{s}}= \begin{cases}\frac{M_{\mathrm{c}}}{\rho L} & M_{\mathrm{c}} \geq 0 \\ 0 & M_{\mathrm{c}}<0\end{cases}
$$

where $\rho$ is the density of water and $L=3.3 \times 10^{5} \mathrm{~J} \mathrm{~kg}^{-1}$ is the specific latent heat of melting. The daily melting rates $\left(a_{\mathrm{s}}\right)$ estimated by the energy-budget calculations were in good agreement with direct ablation measurements at all the AWSs (Fig. 3).

The daily net radiation was calculated as

$$
R=Q_{\mathrm{i}}(1-\alpha)+I_{\mathrm{i}}+\Delta I_{\mathrm{i}}-I_{\mathrm{O}},
$$

with $Q_{\mathrm{i}}$ as the incoming shortwave radiation, $I_{\mathrm{i}}$ and $l_{\mathrm{o}}$ the incoming and outgoing longwave radiation, respectively, and the surface albedo $(\alpha)$ based on observation and varying with the timing of snow to firn/ice transition. According to de Ruyter de Wildt and others (2003), the glacier boundary layer above Breiðamerkurjökull outlet (Fig. 1) is generally not thick enough to influence the incoming longwave radiation $\left(\boldsymbol{l}_{\mathrm{i}}\right)$. Our long-term data, however, strongly indicate the variation of $l_{i}$ at western and northern Vatnajökull is lower than changes in $\sigma T_{S}^{4}$ and higher than in $\sigma T_{\mathrm{G}}^{4}$ ( $\sigma$ being the Stefan-Boltzmann constant), i.e. the cold glacier boundary layer affects $I_{i}$ but is not thick enough to eliminate effects of the warm air above. Further, the glacier boundary layer may become thicker with increased $T_{S}$. Therefore, the changes $\Delta I_{\mathrm{i}}$ from the present longwave radiation $l_{i}$ were assumed to be intermediate between those of $\sigma T_{\mathrm{G}}^{4}$ and $\sigma T_{\mathrm{S}}^{4}$.

Given our second scenario, calculations predict enhanced summer melting caused by increased eddy fluxes $\left(H=H_{\mathrm{d}}+H_{1}\right)$ and net radiation as shown in Figure $9 \mathrm{c}$ and $\mathrm{d}$. The net radiation is more modified by the increased longwave radiation than reduced surface 
Table 1. Observation periods, the surface slope $(\phi)$ and the constants $a_{1}, a_{2}$ and $b_{1}$ of Equations (1-2)

\begin{tabular}{|c|c|c|c|c|c|c|c|c|c|}
\hline \multirow{2}{*}{$\begin{array}{l}\text { Elevation } \\
\text { ma.s.I. }\end{array}$} & \multirow[t]{2}{*}{$\begin{array}{l}\text { Summers of } \\
\text { observation }\end{array}$} & \multirow{2}{*}{$\begin{array}{l}\phi \\
\circ\end{array}$} & \multirow[t]{2}{*}{$a_{1}$} & \multirow{2}{*}{$\begin{array}{l}\mathrm{a}_{2} \\
{ }^{\circ} \mathrm{C}\end{array}$} & \multirow{2}{*}{$\begin{array}{c}b_{1} \\
\mathrm{~m} \mathrm{~s}^{-1}{ }^{\circ} \mathrm{C}^{-1}\end{array}$} & \multicolumn{4}{|c|}{$\begin{array}{l}\text { the temperature changes in Equation (1), and including the wind- } \\
\text { speed changes in Equation (2), respectively }\end{array}$} \\
\hline & & & & & & \multirow{2}{*}{$\begin{array}{l}\text { Elevation } \\
\text { ma.s.I. }\end{array}$} & \multirow{2}{*}{$\begin{array}{l}\text { a. } \\
\text { m w.e. }\end{array}$} & \multirow{2}{*}{$\begin{array}{l}\text { b. } \\
\text { mw.e. }\end{array}$} & \multirow{2}{*}{$\begin{array}{l}\text { c. } \\
\text { mw.e. }\end{array}$} \\
\hline Brúarjökull & & & & & & & & & \\
\hline 1550 & $\begin{array}{l}\text { 1996, } \\
2001-03\end{array}$ & $\sim 0.0$ & $0.46 \pm 0.07$ & 3.86 & $0.00 \pm 0.10$ & \multicolumn{4}{|l|}{ Brúarjökull: } \\
\hline \multirow{2}{*}{$\begin{array}{l}1150-1200 \\
850\end{array}$} & 1994-2003 & $\sim 0.8$ & $0.25 \pm 0.03$ & 4.65 & $0.25 \pm 0.06$ & 1550 & 0.9 & 1.8 & 1.8 \\
\hline & $\begin{array}{l}1996-97 \\
2001-03\end{array}$ & $\sim 1.8$ & $0.15 \pm 0.03$ & 4.36 & $0.39 \pm 0.04$ & $\begin{array}{l}1150 \\
850\end{array}$ & $\begin{array}{l}2.1 \\
3.6\end{array}$ & $\begin{array}{l}3.7 \\
5.3\end{array}$ & $\begin{array}{l}4.0 \\
6.3\end{array}$ \\
\hline \multicolumn{6}{|c|}{ Köldukvíslarjökull: } & \multicolumn{4}{|c|}{ Köldukvíslarjökull: } \\
\hline \multicolumn{6}{|c|}{ Tungnaárjökull: } & \multicolumn{3}{|c|}{ Tungnaárjökull: } & 4.2 \\
\hline 1450 & 1997-2003 & $\sim 1.4$ & $0.24 \pm 0.03$ & 5.39 & $0.18 \pm 0.06$ & 1450 & 1.5 & 3.2 & 3.4 \\
\hline 1100 & 1999-2003 & $\sim 1.3$ & $0.33 \pm 0.06$ & 5.54 & $0.25 \pm 0.09$ & 1200 & 1.9 & 3.7 & 4.0 \\
\hline 755 & 1999-2000 & $\sim 5.8$ & $0.22 \pm 0.04$ & 1.95 & $0.30 \pm 0.06$ & 755 & 5.6 & 7.8 & 8.4 \\
\hline
\end{tabular}

albedo despite earlier exposure of the previous year's summer surface. The wind-speed changes affect the turbulent eddy fluxes and the ablation at an increasing rate at the lower elevations (Fig. 9; Table 2). For $\Delta T_{\mathrm{S}}=+3^{\circ} \mathrm{C}, \Delta T_{\mathrm{G}}$ calculated with Equation (1) and $\Delta u_{\mathrm{G}}=0 \mathrm{~ms}^{-1}$, the present summer melting increases by $\sim 1 \mathrm{~m}$ w.e. at $1550 \mathrm{~m}$ on Brúarjökull and $\sim 2 \mathrm{mw}$.e. at $755 \mathrm{~m}$ on Tungnaárjökull (Table 2, columns a and b). Melting at the other stations increases by $\sim 1.4-1.8 \mathrm{~m}$ w.e. Including the wind-speed changes in Equation (2), the melting rates would not change at $1550 \mathrm{~m}$ on Brúarjökull, but would increase by $6-8 \%$ at the other sites (Table 2, columns b and c). The exceptionally high difference of $19 \%(5.3-6.3 \mathrm{~m}$ w.e. in Table 2) at $850 \mathrm{~m}$ on Brúarjökull is partly due to the increase in the absorbed net solar radiation (Fig. 9d). At $1100 \mathrm{~m}$ elevation on the steep-sloping Köldukvíslarjökull, summer wind speed is considerably higher than at the other sites listed in Table 2, explaining the relatively small difference ( $2 \%$ increase).
Table 2. Column a: May-August ablation in 1996 on Brúarjökull and Köldukvíslarjökull and in 2000 on Tungnaárjökull. Columns b and c: average May-August ablation for $\Delta T_{\mathrm{S}}=+3^{\circ} \mathrm{C}$, using only emperature changes in Equation (1), and including the windchanges in Equation (2), respectively

\section{CONCLUSION}

During the ablation season, Vatnajökull develops its own microclimate with persistent glacier winds. The wind field is created by the temperature difference between the boundary layer over the melting glacier and the free atmosphere and the rising air over the warmer lowland environs of the glacier. The variations in speed of the glacier wind can be related empirically to the temperature fluctuations of the lowland environs of the ice cap. This suggests that climate warming would be accompanied by stronger glacier winds, producing stronger turbulent fluxes and increasing the melting rates in the lower ablation areas of ice caps in Iceland.

\section{ACKNOWLEDGEMENTS}

The work was supported by the National Power Company of Iceland, the University of Iceland Research Fund, the European Union projects IEMASS (ENV4-CT97-0490) and SPICE (EVK2-CT-2002-00152) and the Nordic project Climate, Water and Energy. Comments from an anonymous

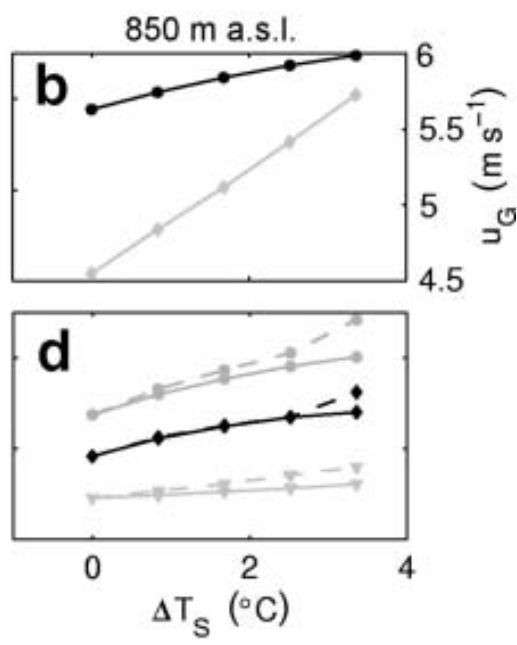

Fig. 9. Calculated temperature, wind speed and energy components at Brúarjökull as functions of assumed regional temperature changes at Eyjabakkar $\left(\Delta T_{S}\right)$. All parameters represent averages over the period May-August. The solid lines in (c) and (d) show the energy budget assuming only the temperature changes in (a) and (b), and the dashed lines when the wind-speed changes are included. 
reviewer and the Scientific Editor W. Harrison greatly improved the manuscript.

\section{REFERENCES}

Björnsson, H. 1972. Bægisárjökull, north-Iceland. Results of glaciological investigations 1967-1968. Part 2. The energy balance. Jökull, 22, 44-61.

Björnsson, H., F. Pálsson, M.T. Guðmundsson and H.H. Haraldsson. 1998. Mass balance of western and northern Vatnajökull, Iceland, 1991-1995. Jökull, 45, 35-58.

De Ruyter de Wildt, M.S., J. Oerlemans and H. Björnsson. 2003. A calibrated mass balance model for Vatnajökull, Iceland. Jökull, 52, 1-20.

Jóhannesson, T. and 11 others. 2004. The impact of climate change on glaciers in the Nordic countries. CWE Project Rep. 3.
Oerlemans, J. 1998. The atmospheric boundary layer over melting glaciers. In Holtslag, A.A.M. and P.G. Duynkerke, eds. Clear and cloudy boundary layers. Amsterdam, Royal Netherlands Academy of Arts and Sciences, 129-153.

Oerlemans, J. and B. Grisogono. 2001. Glacier winds and parameterisation of the related surface heat fluxes. Tellus, 54(5), 440-452.

Oerlemans, J. and 7 others. 1999. Glacio-meteorological investigations on Vatnajökull, Iceland, summer 1996. Bound.-Lay. Meteorol., 92(1), 3-26.

Parmhed, O., J. Oerlemans and B. Grisogono. 2004. Describing surface fluxes in katabatic flow on Breiðamerkurjökull, Iceland. Quart. J. Roy. Meteor. Soc., 130A(598), 1137-1151.

Van den Broeke, M.R. 1997. Momentum, heat and moisture budgets of the katabatic wind layer over a large mid-latitude glacier in summer. J. Appl. Meteorol., 36(6), 763-774. 